DOSSIÊ TEMÁTICO: A medicalização da educação no Brasil e no Chile: diferentes perspectivas

do https://doi.org/10.22481/praxisedu.v15i36.5862

\title{
EXCESS OF ATTENTION: THE CONSTRUCTION OF A DISORDER IN CHILEAN SCHOOLS
}

\author{
EXCESO DE ATENCIÓN: DE LA COMPOSICIÓN DE UN TRASTORNO EN LA \\ ESCUELA CHILENA
}

EXCESSO DE ATENÇÃO: A COMPOSIÇÃO DE UM TRASTORNO NA ESCOLA
CHILENA

\author{
Hugo Sir \\ Universidad de Chile - Chile \\ Université Paris 8 - França \\ Isis Castañeda \\ Universidad de Chile - Chile \\ Esteban Radiszcz \\ Universidad de Chile - Chile
}

\begin{abstract}
The aim of this article is to explore the epistemic and practical conditions of production of the diagnosis of ADHD in Chilean schools. It develops along two main lines: 1) the role of schools in Chile in relation to the characteristics and treatment of this diagnostic category; and 2) the construction of the diagnosis in the classroom, analyzing the treatment of attentional behavior and the configuration of the ADHD Situation. We will conclude by considering student anxiety related to the diagnosis as an indicator of a clash of civilizational orders expressed in the modes of affective modulation performed in the classroom, wherein attempts will be made to resolve institutional violence by way of a demand for individual reform.
\end{abstract}

Keywords: Attention. Chilean school. ADHD Situation.

Resumen: El presente artículo tiene por objetivo explorar las condiciones epistémicas y prácticas de producción del diagnóstico de TDAH en la escuela en Chile. Se desarrolla en dos ejes: 1) la posición de la escuela en Chile respecto de las características y tratamiento de esta categoría diagnóstica; 2) la construcción del diagnóstico en el aula, analizando el tratamiento del comportamiento atencional y la configuración de la situación TDAH. Concluiremos situando la interrogante sobre la inquietud escolar en torno al diagnóstico como indicio de un choque de órdenes civilizatorios expresado en las formas de modulaciones afectivas en el aula, donde se buscará resolver a nivel de una exigencia de rentabilización individual violencias institucionales.

Palabras clave: Atención. Escuela en Chile. Situación TDAH. 
Resumo: O objetivo deste artigo é explorar as condições epistêmicas e as práticas de produção do diagnóstico de TDAH nas escolas do Chile. Se desenvolve em dois eixos: 1) A posição da escola no Chile em relação às características e tratamento dessa categoria diagnóstica; e 2) a construção do diagnóstico em sala de aula, analisando o tratamento do comportamento atencional e a configuração da situação-TDAH. Concluímos situando a questão da inquietude escolar em torno do diagnóstico como uma indicação de um choque de ordens civilizatórias expressas nas formas de modulações afetivas na sala de aula, onde a violência institucional resolve-se através de uma exigência de rentabilização individual.

Palavras chave: Atenção. Escola no Chile. Situação-TDAH.

\section{Introduction}

The diagnosis known as Attention Deficit Hyperactivity Disorder (ADHD) dates to 1980. It owes its initial formulation to the $3^{\text {rd }}$ edition of the Diagnostic and Statistical Manual of Mental Disorders (DSM-III) (AMERICAN PSYCHIATRIC ASSOCIATION, 1980), and from the very start appeared as a particularly controversial category (PARENS; JOHNSTON, 2009; SINGH, 2008; STIGLITZ, 2006). In Chile, as in other latitudes, its incorporation took place at a later date, and being in a way an imported diagnosis (ROJAS et al., 2018), it consequently made scarce reference to the epistemic conditions that framed its reception here. A more profound development of this dimension exceeds the bounds of the present work; we may, however, begin it askance, in order to better understand the prevalence, the conditions, and the singular characteristics of this diagnosis in Chile.

In 1973, a year otherwise in no way indifferent to the country in question, Bravo edits a book entitled "Trastornos del aprendizaje y de la conducta escolar. Psicopatología de la disfunción cerebral infantil"" (BRAVO, 1977). His intention is to frame in the most urgent way possible, and with the most established scientific knowledge available, the diagnosis that preceded ADHD: minimal brain dysfunction. We will encounter here a series of elements that will be repeated tirelessly to this day in the discussion regarding the characteristics of children who can be cataloged with this label. It seems particularly relevant here that as regards that nosographic description, the author points to the importance of school, being the sole context that reveals these behaviors as problematic. This is due to the fact that, at that time, the principal inquiries into child psychiatry on a broad scale are made in schools, and refer to these kinds of behavioral and learning disorders, which require a scientific description that allows

1 [Translator's note] "Learning and Student Behavioral Disorders: Psychopathology of Cerebral Dysfunction in Children". 
practitioners to distinguish them relative to other, previously defined problems, for example, "mild mental retardation or pedagogical immaturity" (BRAVO, 1977, pg.15). On another level, Bravo explicitly states that the diagnostic approach to this syndrome:

[...] by its very nature, comprehends neurological, psychological, psychiatric, pedagogical, and social aspects that complicate even more its appropriate diagnosis, as this requires an integrated interdisciplinary perspective that is not always possible to achieve in everyday pedagogical or clinical practice (ibid.).

Two precedents reside in this archaeological element, understood as a hint of that which, passing through diverse and formally divided fields of knowledge, acquires a certain inclination toward ensemble, a certain number of problems that are connected often in surreptitious ways (FOUCAULT, 1993; RODRÍGUEZ, 2019), and with that, allows us to approach from a variety of perspectives the formulation of the objects that will define the field of knowledge in question - in this case, the liminal zone between neuropsychiatry and education. On the one hand, the diagnosis is described as strictly scholastic; that is, it might not be problematic if not for certain demands of the educational institution. On the other hand, if this is the case, then the study and definition of the disorder require, before becoming vulgate in fund-seeking university departments, an inter- or transdisciplinary analysis.

The combination of symptoms, which had been around for more than 50 years, Bravo tells us, "finds its roots in neurology and prolongs its consequences in pedagogy" (idem, p. 16). And, nevertheless, proud of a text based on empirical observation ${ }^{2}$, he will tell us in the introduction to the second edition that the main difference between it and the first lies in the educational experience [he'd had] of observing children with specific learning disorders who "didn't have specialized teachers capable of rehabilitating them." This leads him to redefine the specificity of the object of his investigation as student behavior and, specifically, "a few neuropsychological investigations that allow us to better understand the relationship between the syndrome of mild mental retardation and problems at school" (idem, p. 19).

What is, then, from our vantage, the problem with school and, at the same time, with part of the epistemic conditions that influenced the local reception of the diagnosis that, according to a foreign rubric, became official in 1980? Well, problems quite well-known in contemporary (hegemonic) descriptions of ADHD: impulsive and disruptive behaviors, the danger that these might lead to addictive or criminal behaviors, inability to calm down and meet

2 Research that, the author tells us, began in 1964 with a team at the Hospital Luis Calvo Mackenna, a place that remains relevant to the study of ADHD in Chilean children to this day. 
the demands of school — without a doubt, a series of problems that would demonstrate adaptive difficulties. Having said that, one precise passage will allow us to connect with what we hope to develop further in this article. The author tells us that though impulsivity and aggressivity, disproportionately common in school environments, "maintain a relationship to the environmental situation [referring to the "familiar-scholastic environment"] and the level of preexisting emotional tension (...), they also appear as a result of a greater 'instinctiveness' 3 [sic] in the behavior" (idem, p. 127). The openly expressed intention of the author is, through his research, to make it known that these problems, expressed in and through school, did not evidence "stupid" or "lazy" children but rather issues that took root in children's minds, in human minds, and that therefore were treatable. Doesn't this cerebral instinctiveness sound like something that needs to be colonized (BURMAN, 2019), civilized (ELIAS, 1990, 1998), subjected to yet another intelligent management of affects (LARA et al., 2017), this time founded in biology?

The link between ADHD and civilizing demands has been suggested before, though it has not been properly developed (CALIMAN, 2008, 2012; LAKOFF, 2000). Be that as it may, it seems to us highly relevant when it comes to comprehending that which, through the diagnosis, is being problematized in Chile. In effect, in understanding the ways in which mental health categories are assembled, it is also possible to arrive at ways of establishing shared understandings of anxieties of an order that exceed the medical definitions thereof (EHRENBERG, 2010). In this sense, the prevalence of the diagnosis in Chile, tripling the rates commonly observed in the international arena (DE LA BARRA et al., 2012; THOMAS et al., $2015)^{4}$, as well as its peculiar characteristics here, for example: 1) the rapid jump in its prevalence between 2009 and 2013 (Ministerio de Educación (MINEDUC), 2009c; Ministerio de Salud (MINSAL), 2013), a fact that is reflected in Chilean imports of Metifenidato (Ritalin ${ }^{\circledR}$ ) which, between 2006 and 2017 increased by 450\% (Cámara de Diputados de Chile, 2019); and 2) the apparent predominance of the attentional dimension, which takes precedence in the ways the diagnosis is described, demarcated, and managed in Chile (Bergey et al., 2018), invite us to involve those other social and academic fields that frame the singular visibility of the object in question, that is, the episteme (FOUCAULT, 1993) in which the phenomenon not only acquires its existence, but also in which it seems able to connote concerns that exceed it as a medical

3 [Translator's note] "Instintividad" in the original Spanish.

4 Reaching in children between the ages of 4 and 11 years old an average of 15.5\%, as shown by (VICENTE et al., 2012); whereas internationally the rate hovers around 5 or $6 \%$, reaching $11 \%$ only in the United States, in which context ADHD was considered a cultural malady up until 1980. See: (BERGEY et al., 2018; CONRAD; BERGEY, 2014; WENDER; TOMB, 2017; STIGLITZ, 2006). 
category and, therefore, would allow us to comprehend the ways in which it is linked to problems that apparently are strictly educational.

With these objectives, then, the article will develop along the following lines. In the first place, we will describe the methodology employed in this collect research project by the team from the Laborotorio Transdisciplinar en Prácticas Sociales y Subjetividad (LaPSoS) $)^{5}$ in the Department of Social Sciences of the University of Chile, which is responsible for these relfections, this publication being the result of more than 3 years of work ${ }^{6}$. Secondly, the diagnosis being linked, even before its actual formulation, to a problem in schools, we are obliged to examine what is peculiar about the role of schools in Chile that translates into the singular characteristics that this nosographic category displays in our country. Thirdly, we will propose a reading of the ways in which the diagnosis is constructed within classrooms, and how the tension produced by the role of schools in Chile is translated therein as attention to schooling, mobilized as attention to [students'] classroom attention, individualizing and substantializing the problem. Finally, we will explore how how this phenomenon is revelatory of a clash of civilizational orders expressed in a dimension that is fundamental to this process: the affective modulations in the relations between generations (ELIAS, 1998). At the same time, attempting to resolve institutional violence on an individual level (FASSIN, 2016) can lead to impediments to transformations which, as they insist on developing, on attempting to modify institutions, appear-to schools and their actors-as persisten malaise (ROLNIK, 2019).

\section{Methodology}

Our collective research began in 2017 with a project titled "Trajectories of Malaise in Children and Adults Diagnosed with ADHD: Social and Subjective Experience of a Multifarious Suffering," supported with a grant from the Laboratorio Transdisciplinar en Prácticas Sociales y Subjetividad (LaPSoS) in the Department of Social Sciences of the University of Chile. Thanks to this funding, we were able to shape an empirical study that, still ongoing, contemplates, to date:

5 [Translator's note] Transdisciplinary Laboratory on Social Practices and Subjectivity.

6 We take this opportunity to thank the entire team in whose company the reflections here expressed have emerged. Being a properly collective work, we no longer know with certainty which ideas pertain to whom, a fact that seems to us, in any case, a blessing. Of course, since it is we[, the authors,] who express them here, we take full responsibility for any mistake or oversight, which are nothing more than the way in which knowledge appears first as a search for truth, as a constant mapping of that which fails and which, therefore, allows us $a$ posteriori to fail better. 
- 3 brief ethnographies of 3-4 months duration, each in one of three educational institutions with divergent characteristics: a) a public school in a middle/upper-middle class district, which is attended, nevertheless, by a large number of working class students; $b$ ) a semi-private ${ }^{7}$ school in a middle/lower-middle class district; c) a private school in an upper class district ${ }^{8}$.

- 23 interviews with adults and children who had been diagnosed with and/or treated for ADHD.

- 7 interviews open to children and their parents and/or primary guardians. 4 boys and 3 girls between the ages of 7 and 13, contacted through ethnographic observation, each having been diagnosed with and treated for ADHD.

- 7 interviews with mental health professionals.

- 4 discussion groups with teachers, with adult men and women who had been diagnosed with ADHD in their childhoods, and with mental health professionals.

For the present work, we privilege analysis of the first two ethnographies mentioned, together with the interviews of children and their guardians and of adults who had been diagnosed with ADHD. As a way of establishing a shared understanding of our analytical approaches, we used strategies that follow the categorical exploration of qualitative analysis (NAVARRO; DIAZ, 1998; VALLES, 1997), together with elements of the sociological analysis of discourse (RUIZ, 2009 and 2014) and of situational analysis (CLARKE et al., 2015), which allowed us to integrate a variety of materials and the discussions that arose between members of our research team, placing these in relation to extratextual elements related to a reading of the educational problem in Chile, based on second order analysis and official documents. Of course, ethical protocols were followed at each stage of research, and the identities of participants will be safeguarded in the present article and in perpetuity.

\section{The Problem with Schools in Chile}

In May of 2006 the most massive and sustained protest since the end of the dictatorship erupted in Chile. Initiated by high school students, it managed to gain the support of up to $80 \%$

\footnotetext{
7 Up until the [educational] reform initiated during the last presidential term of Michelle Bachelet (March 11, 2014 - March 11, 2018), these schools were categorized as "subsidized-private" institutions, and as such, were administered by for-profit private interests, even as they received funds directly from the State through a system of vouchers, which will be explained in greater detail in the following section. Today, this category is mutating, and these institutions are passing from private owners to non-profit foundations. The awarding of subsidies on demand continues, however, unaltered.

8 Chosen according to criteria established by the Asociación de Investigadores de Mercado (AIM) [Association of Market Researchers], 2012.
} 
of the national population, according to contemporary statistics (DOMEDEL; PEÑA y LILLO, 2008). This level of adherence manifested in the streets, school occupations, and public opinion polls, and was rooted in and bound together by the ways in which, by advancing beyond the typical economic demands that resurfaced every school year and challenging the Ley Orgánica Constitucional de Enseñanza (LOCE) $)^{9}$ promulgated by Pinochet a few days before leaving office, it exposed the inner workings of the public education system (RADISZCZ, 2009). In effect, what begins to be questioned ever since this so-called Penguin Revolution ${ }^{10}$ is the role that education plays and the place it occupies on the national scene. The slogan, which would be taken up again in 2011 by striking university students, was first formulated in this moment: the aspiration for "free, quality, public education." Such massivity, support, and persistence cannot be understood without making reference to a kind of affective contract that had organized the hopes and disappointments of the generation brought up during the dictatorship: meritocracy (MAYOL et al., 2013).

In the 90s it could be observed how the discourse surrounding merit was updated and consolidated. In this sense, on the one hand, it is evident that the history of merit is longstanding in the country, specifically in opposition to what, in this territory, is known as a pituto ${ }^{11}$ (BAROZET, 2006). And, at the same time, it is clear that its meaning, its symbolic and affective role breaks down with the advent of the student protests (ARAUJO; MARTUCCELLI, 2015). The history of merit, as it were, had organized ways of understanding social justice that, in the face of the dismantling of a state of guaranteed social rights that took place during the dictatorship and was consolidated during the formally democratic continuation thereof (GÁRATE, 2012), it acquired a markedly paradoxical feature, insofar as it appeared as the only means of salvation, and at the same time as productive of new sentiments of injustice (ARAUJO; MARTUCCELLI, 2012: MAYOL et al., 2013).

This paradox emerges in relation to the model of social relations, described as neoliberalism, that makes the dimensions of merit and pituto, which had been supposed ethical opposites, converge in practice (ARAUJO, 2016; MARTUCCELLI, 2012). Schools, and with them education in general, come to be seen as the only means of salvation, the place where through merit a person can raise their social standing, as it is conceived of as where one acquires

9 Organic Constitutional Law on Education.

10 [Translator's note] Coined as such due to the way that students in uniform resemble and are popularly referred to as penguins.

11 Understood as the colloquial form by which a received favor is referred to in Chile, generally, from a person higher up in the social hierarchy, which allows the recipient to enjoy a benefit that would be difficult to otherwise access. It is, in this way, an operation of informal networks. 
both formal credentials and informal networks. Personal and familiar effort involve merit and pituto simultaneously, complicating the tensions that run through schools (ARAUJO; MARTUCCELLI, 2015; BAROZET, 2006).

On the one hand, that expectations concerning the valuation of merit through education be disappointed is inherent to the educational system; the more people earn technical and academic diplomas, the more these are devalued, reproducing social differences and legitimizing these as differences between the [quality of their respective] diplomas (BORDIEU; PASSERON, 2005). As the proclaimed educational promise displaces the problem of access to education, social alchemy operates, transmuting social differences into differentials of talent, merit, or effort (BOURDIEU, 2007). Diplomas become increasingly stratified, requirements made more strict, and the promise of social mobility associated with formal education becomes ever dimmer (ARAUJO; MARTUCCELLI, 2015).

On the other hand, however, a phenomenon that seems to be something of a singularity with respect to Chile, the unofficial dimension of the networks one can access through education, gains valence. In this sense, the demand for public education exposed, before the breach of the official promise, the functioning of this sinister and unconfessed contract, in which the nonexistence of free, quality, public education makes the quality of education coincide with its price, and in this way so too the networks formed within this stratified educational system assure the reproduction of classes, above and beyond and nearer at hand than the problem of diplomas, through their preservation of the power of personal favors (ARAUJO; MARTUCCELLI, 2015; RADISZCZ, 2009).

Institutionally, it is debt, the copay, and financing-on-demand through so-called vouchers (INZUNZA, 2009) that structure the actual tensions in the Chilean educational system, following in complex ways the parameters of the subsidiary state as defined constitutionally (ACEITUNO; RADISZCZ, 2016) ${ }^{12}$. Such a state of affairs makes material the

12 Until 2017 the Chilean school system (elementary and secondary) maintained a macrostructure inherited from the transformations implemented by the dictatorship in the 1980s. The main features of this macrostructure include: 1) the so-called "municipalization" [of a plethora of government functions], which handed over administrative and financial control [of schools] to these territorial bodies, reproducing in schools the social and economic differences of their respective inhabitants; and 2) the existence of a tripartite system [of education], wherein, alongside those schools belonging to municipal governments and those belonging to private interests (traditionally associated with religious organizations), a mixed system is developed through which a variety of wealthy investors buy up schools which in turn receive state funding by way of a subsidy-on-demand or voucher. These are known as the "private-subsidizeds" and, theoretically they would allow for families to choose freely on the educational marketplace, encouraging competition between schools for excellence. The student protests exposed what in practice was a systematic impoverishment of public schools and a deepening of social stratification, yet again measured by relative acquisitive power (ORELLANA, 2010; INZUNZA, 2009; RADISZCZ, 2009). In the second term of Bachelet, some elements [of the student movements' demands] were taken up, such as the demand for "demunicipalization" and the reworking of the system of subsidized schools, 
symbolic pressure that, associated with its informal functioning, schools organize. Schools, stratified by quality of the education and the networks they provide, according to the substantial differences between what different families can pay (ORELLANA, 2010), are consequently impoverished based on preexisting economic inequalities, and with this reality are made to face the paradoxical and some say impossible demand of achieving social equity through education (MASCAREÑO, 2005).

Schools, and the educational system in general, from which a social justice that their infrastructure denies in practice is discursively demanded, become a potent source of anxiety. Such tension, made explicit during the social protests that have recurred since 2006, is reinforced by the imperatives of inclusion which, being contractual obligations of the state with international governing bodies, begin to materialize in 2008, producing a transformation of the classroom that, at the same time, skyrockets the diagnoses associated with behavioral and learning difficulties, especially ADHD (Ministerio de Salud (MINSAL), 2008; VICENTE, SALDIVIA et al., 2012). Because even though modifications to the educational system begin in 1998 which tend to broaden curricula in line with newly acquired international obligations (Ministerio de Educación (MINEDUC), 2009b), confirming a demand for universality where segregation reigns, it is not until 2008 that the so-called Law of Preferential Subsidy is passed (Ministerio de Educación (MINEDUC), 2008) which, recognizing the many demands that press on schools, seeks to technically manage the existing tension.

It attempts, on the one hand, to meet the state's commitments to tend towards more inclusive schools and, on the other, to recognize and address the persistent inequalities intrinsic to the establishments. Nevertheless, it does not modify the general system of funding, but instead reinforces it. Schools receive a larger subsidy for each child that qualifies and signs up for the preferential subsidy. Their value of the voucher they receive is increased. At first this law focused on those who, being considered "vulnerable" for being poor, require more resources for their education. In this sense, the link between the "penguin demand" and the spirit of this law is evident, as is, unfortunately, the null effect it achieved in that which it proposed to do (ELACQUA, 2012).

giving rise in November, 2017 to the so-called New Public Education Law. Taken together with the School Inclusion Law of 2015, this has been the most profound transformation of public education in Chile since [the passing of the constitution in] 1980, the implementation of which will continue until 2025 (Ministerio de Educación (MINEDUC), 2015). In turn, the current government of Sebastián Piñera has passed and has attempted to pass other legislative initiatives that point to divergent or opposing goals, which without a doubt will intensify the tension that traverses schools (BELLEI, 2018). 
Nevertheless, in 2009 supplementary and detailed criteria are established, as part of the state's obligations to vie for greater inclusion in schools, to determine what kinds of conditions and/or diagnoses would be admitted into this preferential system under the auspices of Special Educational Needs (Ministerio de Educación (MINEDUC), 2009a). The result is that diagnosed children have become commercially attractive for precarious schools. In parallel, we see increasing state intervention in schools and classrooms.

The state, upon dolling out more resources for the promotion and management of diversity in classrooms, demands the formation of a team of other professionals ${ }^{13}$ duly identified and differentiated, under the auspices of the Program for School Integration, and made responsible inside and outside the classroom for children who, for a variety of reasons, have been cataloged as having Special Educational Needs. From then on, one of the diagnoses that has most dramatically increased is, precisely, ADHD. For this reason, among others, the thesis that the disorder is being overdiagnosed has garnered broad public support. Nevertheless, we believe it is fundamental to grasp the emergence of what we call the ADHD Situation based on a detailed understanding of the activity of the Program for School Integration inside the classroom.

\section{There is no overdiagnosis. The phenomenon includes the excess}

Various debates and controversies related to ADHD have traditionally focused on the prevalence of the diagnosis and on the medicalization of child behavior, to the detriment of perspectives that shed light on: 1) the social uses of overdiagnosis, 2) prescription drug consumption, and 3) the subjective experience and social trajectories of children (BÉHAGUE; LÉZÉ, 2015; BERGEY et al., 2018; COTTET et al., 2019; ROJAS et al., 2018; URIBE et al., 2019). This has meant that our attention has been focused on attentional conduct and the individual consequences of the diagnosis, rather than on subjective and social experiences. In this sense, the idea of overdiagnosis goes hand in hand with a mode of problematization that is

13 The Program for School Integration is defined as an "educational strategy focusing on inclusion" in order to "support the participation and learning achievement of every student, offering resources and equalizing access to educational opportunities, especially for those who require more assistance in order to progress in their learning," to which end they literally pretend to change their "approach, from deficit to the elimination of barriers" (Ministerio de Educación (MINEDUC, 2016, p. 9). A new approach to "pedagogical management" is constituted (idem, p. 10) in order to respond to the "broad array of learning needs" (idem, p. 11). Specialized teachers, professional teaching assistants, and other professionals associated with the areas of psychology, education, and health are employed toward these ends (ibid.). 
linked to indices of prevalence and focused on individual symptoms, losing sight of what has been called the ADHD Situation (COTTET et al., 2019; REYES et al., 2019).

From this perspective, what interests us is to approach the ways in which the diagnosis of attentional deficit with hyperactivity is constituted, based on ethnographic study of and interviews with diagnosed children and adults who had been diagnosed in their childhoods. We will begin with an ethnographic description of the classrooms in two Chilean schools. What's more, it should be pointed out that in the interviews with both children and adults, the basis justifying the diagnosis in schools was established, without exception, as what some interviewees referred to as "anxiety" and/or "restlessness" in the classroom; this is the problematic target of the diagnosis in question.

Initially, we will tarry with two ethnographic descriptions. The first was conducted by a teacher during her working day and later narrated to the ethnographer, about a student diagnosed with ADHD in a semi-private school in a middle/lower-middle class district. The second description corresponds to the observations of an ethnographer in a public school in a middle/upper-middle class district:

She likes to be the center of attention. She prefers to do what she wants. She doesn't listen. She doesn't pay attention to details. She forgets things. She answers impulsively. She's disorganized. She's always moving around. She runs or jumps up on benches when her classmates are watching. She interrupts people (Notas etnografía, Cuaderno de campo 1).

When Antonio tries to participate by raising his hand, something that happened in many of the observed classes, he is simply not seen. Until, that is, Antonio decides to answer or participate by speaking up, without respecting anybody's turn. He is therefore reprimanded; the teacher calls attention to him (Notas etnografía, Cuadernos de campo 2).

If we observe the discursive constructions surrounding attention here, we'll note at least two diametrically opposed meanings attached to "calling it" in the classroom setting: 1) the interruption of the adult-centered social order attributed to a child ("She likes to be the center of attention") and 2) the verbal reprimand of an adult teacher directed at a child ("The teacher calls attention to him").

The fluctuation of attention beyond the expected flows, which is to say-directed at the teacher, is accompanied, in the ethnographic descriptions, by an interruption ("She interrupts people"), which is described hand in hand with the disruption ("She answers impulsively. She's disorganized"), (he participates "without respecting anybody's turn"). This interruptiondisruption connotes an apparent failure in the self-management of impulsivity and affectivity 
(BOWDEN, 2014; CALIMAN, 2008; LAKOFF, 2000) that interrupts the expected order within the classroom, straining norms of social harmony established therein.

These discursive configurations seem to treat attention as a substance, as loot, and from that [conceptual] treatment arises the necessity to attach verbs to attention (call, hog, pay, focus). To substantialize the action of paying attention is to articulate that action in such a way as to depoliticize the questioning of social order and organization in the classroom, converting the behavior into a deficit and affective impulsivity into cerebral instinctiveness [sic] (EHRENBERG, 2018; MALABOU, 2012). The ambivalence surrounding the formula "to call attention," alternately a conquest and a sanction, arises therefrom. It seems entirely appropriate, then, in light of these contradictions, to demonstrate a political dimension that is indeed in play here, one that resists adult discursive formulations that are (re)iterated in the classroom and which tend to reduce the question of [sociopolitical] order to one of the [quality of] children's behavior.

In this way, we begin to approach the idea of situation, in this case the ADHD situation, wherein attention plays a central role as loot that is in dispute and which organizes the political condition of that situation (COTTET et al., 2019). The teacher's capturing of children's attention, by associating a behavior with a proper name and beyond the limits of a specific moment, is precisely - as one of the ethnographic notes signals - a way of converting an event, which is to say a contextualized and fluctuating situation, an open situation composed of forces, into a substance: attention as loot. It is this sleight of hand that permits one to speak of a deficit. The ethnographic observations demonstrate that this becomes problematic when children displace the expected attentional flow in the classroom, that is when they distract the pedagogical authority. In this way, that which we've called the ADHD Situation expresses a problematic articulation with respect to the ways in which impulses are enlisted (or not) in the service of the institution. In Elias' terms (1990, 1998), converting an event into substance distracts us from the question of the (re)production of the problematic relations between generations, which involves, precisely, an affective modulation based on [contesting] civilizational orders, in other words, a colonization of desire (BURMAN, 2018; ROLNIK, 2019).

Now then, with respect to the institutional mode of tackling that which is presented as problematic under the figuration of the ADHD diagnosis, we return to the activity of the Program for School Integration (PSI). As we've stated, in the Chilean education system, the PSI is the instrument par excellence charged with working with those students marked by an ADHD diagnosis. That is, they manage that which gives a name to the liminal zone that 
diagnosed children open up: special educational needs (Ministerio de Educación (MINEDUC), 2009). The PSI aims to improve the inclusion of students by strengthening their differences, not in any old way, but rather by insuring that these are integrated into the [desired] functioning of the classroom (GAULEJAC; HANIQUE, 2015). The work of this instrument differs from traditional educational and administrative labors in schools, and is treated as a subspace oriented towards individualized assistance which is carried out in parallel to the work of the teacher both inside the classroom and during extracurricular activities.

With respect to the functioning of the PSI in the classroom, the following fragments described by the ethnographer in the public school prove eloquent:

Diego begins to converse without paying "attention" to the class. The PSI professional does not delay in appearing at his side, commenting that, 'He's out of control this week.'

The teachers call for order a couple of times, singling out the names of Claudia and Benjamín, and immediately a PSI professional enters the classroom, makes a beeline to Benjamín, and administers his medication (Notas etnografía, Cuaderno de Campo 2).

In the first place, we want to highlight the PSI professional's almost immediate intervention in the second case and their preemptive intervention in the first case, which is initiated even before the child receives an official call to attention or reprimand from the teacher. The velocity in interpreting an action as common as "conversing" through the formulation "he's out of control this week" is likewise of interest. On this point, the rapid and individualized intervention of the PSI, in which the professional seems to have complete knowledge about who is the problem child, is striking - and note that the problem comes down to $a$ who correctly individualized, not one that involves others or the school at large, and thus can be directly addressed by administering a medication. This individualized approach in terms of the relationship child-diagnosis-treatment, according to the logic of the Special Educational Needs program, involves the installation of a differential of individual deficits susceptible to rehabilitation, where the PSI seems to configure itself as an instrument disposed to serving as an orthopedic between the deficit and the possibility of making the deficient characteristics functional, eliminating barriers for their incorporation, without necessarily in practice questioning the mechanism.

The movement - from the financial deficit of the scholastic institution, which must turn to any and all kinds of arrangements in order to obtain subsidies and offset the lack of state resources earmarked for education in Chile (such as, for example, the profitability of [enrolling] diagnosed children), to the attentional deficit ascribed to students - can be understood as a local 
tactic that individualizes a [social] problematic, substantializing a deficit that, nevertheless, exists on a pre-individual register, that is, one that is simultaneously both affective and institutional (LARA et al., 2017), exceeding any individual in question (LIEBERT, 2018). That mode of individualizing the deficit is connected to the demands of generating particular ways of performing in school and, thus, of continuing to support ourselves even as we're cast into a social life that promises little to no institutional support. According to this logic, the activity of the PSI is articulated in the mode of humanitarianism described by Fassin (2016), seeking to compensate in the short-term and on an individual basis any and all inadequacies linked to the demands and violence with which the institution operates. In this way, it amounts to an instrument that, in its striving for integration, seems to, without desiring to, (re)situate children as individuals in deficit, whereby, on intervening on an individual basis, it ignores and reproduces state and scholastic violence. And it does so to the degree that it transfers the problem of the deficit in Chilean education at large to a deficit present in individualized children, who should find a way to make their difference profitable or else accept their own failure. Which is all to say, the activity of the PSI is oriented towards the management of children's attention as a way of mollifying the structural tension that permeates schools.

In this way, all of the attention paid to a situation that involves, at the very least, the state, schools, teachers, the Program for School Integration, and students, is crystallized in the figure of a child, who not only should accept and treat their deficit, but also and above all should make it profitable. In this respect, Ilina Singh's $(2005,2013,2014)$ now classic argument is relevant. She proposes that we get to know the "child's perspective," and indicates that through proper treatment they could not only perform according to what is expected of them, but also, in developing feelings of competence, they could form a more satisfactory and coherent image of themselves, one more in line with their desires. In fact, Singh concludes that while treatments are oriented by a social-moral frame (SINGH, 2007), that is, towards the meeting of scholastic obligations, when children explain their motives in treatment, they perceive it as a way of gaining greater freedom over their actions: "to be able to choose" to pay more attention, behave better, or increase their potential for self-realization through the development and strengthening of self-control (SING, 2013, 2014). That is, the imperative to convert deficit into potential is not the sole factor, but rather, the treatment should also produce satisfaction. This last point emerges as a central element in the interviews with adults diagnosed with ADHD in their childhoods, in whose experience, in the "successful" cases, the deficit diagnosed in their childhood has become, through their studies and in their work, a strength in their adulthood. The methods by which this (re)channeling is achieved are not, as claimed in years past, solely 
discipline and work ethic, in school and in work, but also, rather, by finding in their differences something they can pleasurably exploit (DARDOT; LAVAL, 2009). The superposition or displacement of a disciplining that pretends only to "normalize" and annul difference by an effort that motivates the pleasurable exploitation of difference, generates the conditions for a child's (re)entry into the fray of scholastic, and later workplace, demands. This does not, however, deepen their ability and disposition to question the norms that organize the educational system and, with that, their ability and disposition to engage with and participate in the further development of the social justice imaginary initiated and sustained by the massive protests of 2006 and 2011. On the contrary, treatment tends to make the norms more impregnable, it should be obeyed not to negate one's difference, but rather in the service of making yourselves who you really are. These divergent modalities of becoming raise questions about the conflict between civilizational orders to which the prevalence, conditions, and management of ADHD in Chile testify.

\section{Final Reflections}

The epistemic conditions of reception of the attention deficit diagnosis, formulated as such since the 1980s, highlight its constitution as a problem in and for schools. The comprehension of its national singularities invite us to elucidate the social problematization of its reception in Chile, keeping in mind that the language of mental health at times traffic concerns that exceed the reach of the medical profession (EHRENBERG, 2010).

In this sense, the student protests that irrupt in 2006 remain present, in a variety of ways, to this day, pointing to a conflictive friction peculiar to schools in Chile. On the one hand, schools appear as a principal focal point of the discourse surrounding merit which, consolidated in the 1990s, organized the social justice imaginaries of the generation brought up during the dictatorship. On the other hand, schools were interpellated by those student protests, not only for failing to fulfill the promise of social mobility, but also for sustaining informal networks of personal favors (locally known as pitutos) that historically opposed the effective force of merit. Contrary to what was maintained in rhetoric, the tripartite system of education which decimated the public funding of education did not promote a merit-based system that would break with the reproduction of social privileges sustained through the mutual exchange of favors, but instead tended to maintain this reproduction, legitimizing the traffic in favors as corresponding to the free choice of parents and guardians. This successful interpellation organizes to this day, in the midst of a transformation of the education system, a series of legal and normative 
instruments that intervene in schools, seeking to resolve through technical management the political challenge.

In addition, these instruments bear the tension introduced by international agreements, which promote the constitution of more inclusive schools. Universalist pressures on the existing and deeply segregated educational infrastructure are thus reinforced, which in practice translates into the creation of new legal and normative instruments that privilege individual interventions, and in particular, the creation and implementation of the Program for School Integration. One of the results of this process is that within classrooms the attentional problem tends towards individualization and substantialization in order to be more readily managed and resolved, from the standpoint of the needs of schools that are both economically and institutionally precarious. And, nevertheless, we could appreciate that the attentional problem can be better described as a situation. The ADHD Situation is one in which the forces and tensions that run through schools and classrooms constitute the problem, not individual deficits susceptible to reformative improvements and made into special abilities capable of servicing the very norms that individualize them.

The notion of the ADHD Situation is useful precisely as a point of entry into a problem that's in constant (re)production, not a diagnosis or a deficit capable of being cured on an individual basis, but instead, as made manifest in a happening or an event; it makes possible a conceptual movement away from the individual and toward the singular. All that contested attention amounts to loot, bearer of a fluctuating potency that cannot simply be erased, given that:

[...] on the most basic level of living, games of coding and decoding leave room for the possibility that, before being a sickness, deficit, or monstrosity, it is a disturbance of the information system, an <<omission>>. In the final instance, life is that which is capable of erring-in that lies its radical character (FOUCAULT, 2007, p. 55).

This opens the way for an interstitial politics, a politics of error which, in radically accepting crisis as the exposure of a conflict that was always present, we can observe in that which resists or escapes standardization new possibilities for thinking through the link between mental health and politics.

In this sense, and by way of conclusion, it is possible to affirm that the focus on the notion of attention and its circulation, permits us, through its flights, becomings, and movements, to expand our understanding of the problem, moving from the dilemma of the medicalization of childhood and the prevalence of diagnoses, towards questions about the 
subjective position of children ensnared in the ADHD Situation; moving from the notion of a deficit susceptible to treatment and improvement, towards a focus on what fluctuations in attention constantly produce. In this sense, by following flows of attention, it is possible to map new forms of organization in the classroom, where previous organizations produced deficit. The invitation is to politicize the question of attention.

It is the ethnographic material which has allowed us to develop our unresolved questions about other ways of inhabiting the classroom and about other possible or existing strategies for managing attention. In this respect, the following ethnographic observation proves interesting:

A large number of children approached me. They came to engage in one of their favorite, I would later find out, activities: to converse. Something like the collective nature of a class of students [moved them], that which made them be, in effect, a class-group and not merely an aggregate of individuals (...) Before becoming this group, many had already asked me what my role in the classroom was, to which I always responded: 'to watch and to write.' This was obviously an unsatisfactory response, that had to do, in this class, with the very same constitution of the group around me (...) They expressed their curiosity more openly with greater corporal proximity. One of the girls, who has a certain authority with language, did not hesitate to say to me that 'we are the most disorderly class.' And in response to my question asking them what they thought of that, she responds 'we like it, because we are OGs.' Many of her classmates assented, and one of them added: 'the other classes are boring' (Notas etnografia, Cuaderno de Campo 2).

This fragment transports us to various dimensions of the problem. In the first place, the focus is shifted once again from the idea of a deficit of an order other than that expected by the school and the adult world, toward an excess, this time not of the attention that is directed from the adult world toward the child qualified as disruptive, nor excess in terms of the normative injunction, but rather in the sense of the multiplicity of flows in circulation in the classroom. The scene playfully expresses the dimension of childhood as a political challenge for adults and, in this case, the tension over the attention of children will prove to be part of the problem. From this perspective, not only is the intergenerational problem of a performance always lacking or in deficit (re)produced in the classroom, but also, at the same time, a question about possible new forms of congregating bodies, ones that don't merely obey the individualizing exploitation of differences, emerges. From this group's own self-identification as "the most disorderly or OG class," the difficulty of or resistance to inscription in the established order, the scholastic norm, resounds. Which, to our judgment, is a fragment that expresses a civilizational challenge always, in part, out of reach. Childhood will always accompany humanity and its adulthood like an indelible trace, an irreducible remainder in flight from enclosure, minor becomings of political rupture (DELEUZE, 2005; DELEUZE; GUATARRI, 
2002). Finally, in this fragment the dimension of curiosity appears, that attentional flow which escapes any attempt at closure, like an impulse that resists colonization or civilization (BURMAN, 2018; ROLNIK, 2019). In this way, the substantialization of the ADHD Situation is configured as a way to manage orthopedically the interruptions of the attentional flow expected by the institution. Attention is what is politically in play in the classroom, in its fluctuation, in its conquests and retreats, in its capture and valuation, in its circulation, and in its escape.

\section{REFERENCES}

ACEITUNO, Roberto; RADISZCZ, Esteban. Chicago Boys. In: ABARZÚA, M.; ACEITUNO, Roberto; VALENZUELA, R., eds. Chile. Glosario ilustrado del malestar. Santiago de Chile: Social-Ediciones, 2016, p. 29-30.

\section{AMERICAN PSYCHIATRIC ASSOCIATION. Diagnostic and statistical manual of mental disorders, 1980.}

ARAUJO, Kathya. L'inflexion du Chili. Contribution au débat. In: Problèmes d'Amerique latine, Jg. 3 (102), 95-109. 2016.

ARAUJO, Kathya; MARTUCCELLI, Danilo. Desafíos comunes. Retrato de la sociedad chilena y sus individuos. Santiago: LOM Ediciones, 2012.

ARAUJO, Kathya; MARTUCCELLI, Danilo. La escuela y la cuestión del mérito: reflexiones desde la experiencia chilena. In: Educação e Pesquisa, Jg. 41 (spe), 1503-1520. 2015.

ASOCIACIÓN DE INVESTIGADORES DE MERCADO (AIM). Nuevo modelo de grupos socioeconómicos. Santiago de Chile, 2012.

BAROZET, Emmanuelle. El valor histórico del pituto: clase media, integración y diferenciación social en Chile. In: Revista de Sociología (20), 69-96. 2006.

BÉHAGUE, Dominique; LÉZÉ, Samuel. Shaping the modern child. Genealogies and ethnographies of developmental science. In: Social science \& medicine (1982) (143), 249254. 2015.

BELLEI, Cristián, ed. Nueva Educación Pública. Contexto, contenidos y perspectivas de la desmunicipalización. Santiago de Chile: CIAE-Universidad de Chile, 2018.

BERGEY, Meredith R.; FILIPE, Angela M.; CONRAD, Peter; SINGH, Ilina, eds. Global perspectives on ADHD. Social dimensions of diagnosis and treatment in 16 countries. Baltimore: Johns Hopkins University Press, 2018.

BOURDIEU, Pierre. El sentido práctico. Buenos Aires: Siglo veintiuno, 2007. 
BOURDIEU, Pierre; PASSERON, Jean Claude. La reproducción. Elementos para una teoría del sistema de enseñanza. México: Fontamara, 2005.

BOWDEN, Gregory. Disorders of inattention and hyperactivity. In: History of the Human Sciences, Jg. 27 (1), 88-107. 2014.

BRAVO, Luis. Trastornos de aprendizaje y de la conducta escolar. Psicopatología de la disfunción cerebral infantil. Santiago de Chile: Andrés Bello, 1977.

BURMAN, Erica. Fanon, education, and action. Child as method / Erica Burman. London: Routledge, 2018.

BURMAN, Erica. Child as method: implications for decolonising educational research. In: International Studies in Sociology of Education, Jg. 28 (1), 4-26. 2019.

CALIMAN, Luciana Vieira. Os valores da atenção e a atenção como valor. In: Estudos e Pesquisas em Psicologia, Jg. 8 (3), 632-645. (http://www.epublicacoes.uerj.br/index.php/revispsi/article/download/10551/8280). 2008.

CALIMAN, Luciana Vieira. Os regimes da atenção na subjetividade contemporânea. In: Arquivos Brasileiros de Psicologia, Jg. 64 (1), 2-17. 2012.

CÁMARA DE DIPUTADOS DE CHILE. Boletín 11662-04. Modifica la ley General de Educación y la ley sobre Subvención del Estado a establecimientos educacionales, en el sentido de prohibir que se condicione la permanencia de estudiantes al consumo de medicamentos para tratar trastornos de conducta, 2019.

CLARKE, Adele E.; FRIESE, Carrie; WASHBURN, Rachel, eds. Situational analysis in practice. Mapping research with grounded theory. Walnut Creek California: Left Coast Press, 2015.

CLARO, Sebastián. Luche-Mundo. Una metodología para el abordaje responsable y dialógico del TDAH. In: Estudios pedagógicos (Valdivia), Jg. 41 (especial), 31-50. 2015.

CONRAD, Peter; BERGEY, Meredith R. The impending globalization of ADHD: notes on the expansion and growth of a medicalized disorder. In: Social science \& medicine (1982), Vol. 122, 31-43. 2014.

COTTET, Pablo; BÉLIARD, Aude; NAKAMURA, Eunice. Presentation - Concepts, trajectories, and approaches to "agitation" and "non-conforming children": social and cultural experiences in Brazil, Chile and France. In: Saúde e Sociedade, Jg. 28 (1), 6-11. 2019.

DARDOT, Pierre; LAVAL, Christian. La nouvelle raison du monde. Essai sur la société néolibérale. Paris: Découverte, 2009.

DELEUZE, Gilles. Derrames. Entre el capitalismo y la esquizofrenia. Buenos Aires: Cactus, 2005.

DELEUZE, Gilles; GUATTARI, Félix. Mil mesetas. Capitalismo y esquizofrenia. Valencia: Pre-Textos, 2002. 
DOMEDEL, Andrea; PEÑA Y LILLO, Macarena. El mayo de los pingüinos. Santiago de Chile: Radio Universidad de Chile, 2008.

EHRENBERG, Alain. La société du malaise. París: Odile Jacob, 2010.

EHRENBERG, Alain. La mécanique des passions. Cerveau,comportement, société. Paris: Odile Jacob, 2018.

ELACQUA, Gregory. The impact of school choice and public policy on segregation. Evidence from Chile. In: International journal of education development, Jg. 32 (3), 444453. 2012.

ELIAS, Norbert. La sociedad de los individuos. Ensayos. Barcelona: Península, 1990.

ELIAS, Norbert. La civilización de los padres y otros ensayos. Santa Fe de Bogotá, México: Norma, 1998.

FASSIN, Didier. La razón humanitaria. Una historia moral del tiempo presente. Buenos Aires: Prometeo, 2016.

FOUCAULT, Michel. The archaeology of knowledge and the discourse on language. New York: Barnes \& Noble, 1993.

FOUCAULT, Michel. Nacimiento de la biopolítica. Curso en el Collège de France (19781979). Buenos Aires: Fondo de Cultura Económica, 2007.

GÁRATE, Manuel. La revolución capitalista de Chile. 1973-2003. Chile: Ediciones Universidad Alberto Hurtado, 2012.

GAULEJAC, Vincent de; HANIQUE, Fabienne. Le capitalisme paradoxant. Un système qui rend fou. Paris: Éditions du Seuil, 2015.

INZUNZA, Jorge. La construcción del derecho a la educación y la institucionalidad educativa en Chile. Antecedentes para una polémica de 200 años. Santiago de Chile: Observatorio Chileno de Políticas Educativas (OPECH), 2009.

LAKOFF, Andrew. Adaptative will. The evolution of attention deficit disorder. In: Journal of the History of the Behavioral Sciences, Jg. 36 (2), 149-169. 2000.

LARA, Ali; LIU, Wen; ASHLEY, Colin Patrick; NISHIDA, Akemi; LIEBERT, Rachel Jane; BILLIES, Michelle. Affect and subjectivity. In: Subjectivity, Jg. 10 (1), 30-43. 2017.

LIEBERT, Rachel Jane. Psycurity. Colonialism, Paranoia, and the War on Imagination. Abingdon, Oxon: Routledge, 2018.

MALABOU, Catherine. The new wounded. From neurosis to brain damage. New York: Fordham University Press, 2012. 
MASCAREÑO, Aldo. La imposibilidad de la igualdad por la vía educativa. In: Asuntos Públicos (513), Online. 2005.

MAYOL, Alberto; AZÓCAR ROSENKRANZ, Carla; AZÓCAR ORTIZ, Carlos. El Chile profundo. Modelos culturales de la desigualdad y sus resistencias. Santiago de Chile: Liberalia Ediciones Ltda, 2013.

MINISTERIO DE EDUCACIÓN (MINEDUC). Ley Subvención Escolar Preferencial. Ley 20.248, 2008 .

MINISTERIO DE EDUCACIÓN (MINEDUC). Decreto Fuerza de Ley $\mathbf{N}^{\circ} \mathbf{1 7 0}$. Fija normas para determinar los alumnos con necesidades educativas especiales que serán beneficiarios de las subvenciones para educación especial., 2009a.

MINISTERIO DE EDUCACIÓN (MINEDUC). Decreto Fuerza de Ley $\mathbf{N}^{\circ} \mathbf{2}$. Fija texto refundido, coordinado y sistematizado del decreto con fuerza de ley $\mathbf{n}^{\mathbf{0}} \mathbf{2}$, de 1996 , sobre subvención del estado a establecimientos educacionales. Chile, $2009 \mathrm{~b}$.

MINISTERIO DE EDUCACIÓN (MINEDUC). Déficit Atencional. Guía para su comprensión y desarrollo de estrategias de apoyo, desde un enfoque inclusivo, en el nivel de Educación Básica. Santiago de Chile: Ministerio de Educación, 2009c.

MINISTERIO DE EDUCACIÓN (MINEDUC). Ley de Inclusión Escolar. Ley 20.845, 2015.

MINISTERIO DE EDUCACIÓN (MINEDUC). Manual de apoyo a la Inclusión Escolar en el marco de la Reforma Educacional. Santiago de Chile: Ministerio de Educación, 2016.

MINISTERIO DE SALUD (MINSAL). Guía Clínica Atención Integral de Niñas/ Niños y Adolescentes con Trastorno Hipercinético/Trastorno de la Atención (THA). Santiago de Chile, Chile, 2008.

MINISTERIO DE SALUD (MINSAL). Programa Nacional de Salud de la Infancia con Enfoque Integral. Santiago de Chile: Ministerio de Salud, 2013.

NAVARRO, Patricio; DÍAZ, Claudio. Análisis de contenido. In: Delgado, Juan Manuel; Gutiérrez, Juan, eds. Métodos y técnicas cualitativas de investigación en ciencias sociales. Madrid: Síntesis, 1998.

ORELLANA, María Isabel. Una mirada a la escuela chilena. Entre lógica y paradoja. Santiago de Chile: Ediciones SM, 2010.

PARENS, Erik; JOHNSTON, Josephine. Facts, values, and attention-deficit hyperactivity disorder (ADHD): an update on the controversies. In: Child and adolescent psychiatry and mental health, Vol. 3, No. 1, 1. 2009.

RADISZCZ, Esteban. Chili 2006. La révolte des Pingouins ou une politique qui ne serait pas de l'homogénéisation. In: Assoun, Paul-Laurent; Zafiropoulos, Markos, eds. Figures cliniques du pouvoir. Paris: Economica-Anthropos, 2009. 
REYES, Pablo; COTTET, Pablo; JIMENEZ, Alvaro; JAUREGUI, Gabriela. Rethinking medicalization: discursive positions of children and their caregivers on the diagnosis and treatment of ADHD in Chile. In: Saúde e Sociedade, Jg. 28 (1), 40-54. 2019.

RODRÍGUEZ, Pablo. Las palabras en las cosas. Saber, poder y subjetivación entre algoritmos y biomoléculas. Buenos Aires (Argentina): Cactus, 2019.

ROJAS, Sebastián; ROJAS, Patricio; PEÑA, Mónica. From problematic children to problematic diagnosis. The paradoxical trajcetories of child and adolescent ADHD in Chile. In: Bergey, Meredith R.; Filipe, Angela M.; Conrad, Peter; Singh, Ilina, eds. Global perspectives on ADHD. Social dimensions of diagnosis and treatment in 16 countries. Baltimore: Johns Hopkins University Press, 2018, 310-331.

ROLNIK, Suely. Esferas de la insurrección. Apuntes para descolonizar el inconsciente. Buenos Aires: Tinta Limón, 2019.

RUIZ, Jorge. Análisis sociológico del discurso. Métodos y lógicas. In: Forum: qualitative social research, Jg. 10 (2).

RUIZ, Jorge. El discurso implícito. Aportaciones para un análisis sociológico / Implicit Discourse: Contributions to a Sociological Analysis. In: Revista Española de Investigaciones Sociológicas. 2014.

SINGH, Ilina. Will the "real boy" please behave: dosing dilemmas for parents of boys with ADHD. In: The American journal of bioethics : AJOB, Vol. 5, No. 3, 34-47. 2005.

SINGH, Ilina. Beyond polemics: science and ethics of ADHD. In: Nature reviews. Neuroscience, Vol. 9, No. 12, 957-964. 2008.

SINGH, Ilina. Not robots. Children's perspectives on authenticity, moral agency and stimulant drug treatments. In: Journal of medical ethics, Vol. 39, No. 6, 359-366. 2013.

SINGH, Ilina. Authenticity, Values, and Context in Mental Disorder: The Case of Children With ADHD. In: Philosophy, Psychiatry, \& Psychology, Jg. 21 (3), 237-240. 2014.

STIGLITZ, Gustavo, ed. DDA, ADD, ADHD, como ustedes quieran. EI mal real y la construcción social. Buenos Aires: Grama, 2006.

URIBE, Pía; ABARCA-BROWN, Gabriel; RADISZCZ, Esteban; LÓPEZ-CONTRERAS, Eleonora. ADHD and Gender: subjective experiences of children in Chile. In: Saúde e Sociedade, Jg. 28 (1), 75-91. 2019.

VALLES, Miguel. Técnicas cualitativas de investigación social. Reflexión metodológica y práctica profesional. Madrid: Síntesis, 1997.

VICENTE, Benjamin; LA BARRA, Flora de; SALDIVIA, Sandra; KOHN, Robert; RIOSECO, Pedro; MELIPILLAN, Roberto. Prevalence of child and adolescent psychiatric disorders in Santiago, Chile: a community epidemiological study. In: Social psychiatry and psychiatric epidemiology, Vol. 47, No. 7, 1099-1109. 2012. 
VICENTE, Benjamín; SALDIVIA, Sandra; LA BARRA, Flora de; KOHN, Robert; PIHAN, Ronaldo; VALDIVIA, Mario; RIOSECO, Pedro; MELIPILLAN, Roberto. Prevalence of child and adolescent mental disorders in Chile: a community epidemiological study. In:

Journal of child psychology and psychiatry, and allied disciplines, Vol. 53, No. 10, 10261035. 2012.

WENDER, Paul H.; TOMB, David A. ADHD. A guide to understanding symptoms, causes, diagnosis, treatment, and changes over time in children, adolescents, and adults. New York NY: Oxford University Press, 2017.

\section{SOBRE OS AUTORES:}

\section{Hugo Sir}

Doutorado em andamento em Ciências Sociais, Universidad de Chile - Université Paris 8; Docente Universidad Andrés Bello, Santiago, Chile; Membro do Laboratorio Transdisciplinar en Prácticas Sociales y Subjetividad

(LaPSoS). E-mail: hugo.sir.r@gmail.com

(iD http://orcid.org/0000-0002-7815-8268

\section{Isis Castañeda}

Mestre em Psicología Clínica de Adultos, Universidad de Chile; Docente da Facultad de Ciencias Universidad Mayor, Santiago, Chile; Membro do Laboratorio Transdisciplinar en Prácticas Sociales y Subjetividad (LaPSoS). E-mail: isis.castaneda.c@ gmail.com

(iD) http://orcid.org/0000-0002-3916-0170

\section{Esteban Radiszcz}

Doctor en Psicopatología fundamental y psicoanálisis, Université Paris VII; Docente de graduação e pós-graduação na Universidade do Chile, Santiago, Chile; Membro do Laboratorio Transdisciplinar en Prácticas Sociales y Subjetividad (LaPSoS). E-mail: eradiszcz@ gmail.com (iD https://orcid.org/0000-0002-3282-6670 